\title{
THE UKRAINIAN INTEREST RATE PASS-THROUGH IN THE POST-1999 ERA AND THE EFFECTIVENESS OF THE COUNTERCYCLICAL MONETARY POLICY
}

\author{
Chu V. Nguyen \\ University of Houston- Downtown, TX, USA \\ Anna Kravchuk \\ Academy of the State Penitentiary Service, Chernihiv, Ukraine
}

\begin{abstract}
This study investigates the nature of the Ukrainian interest rate pass-through from January 2000 to November 11, 2018-the post-1999 era. The empirical results reveal a relatively high short-run interest pass-through of 0.724100 and a marginally overshooting long-run interest rate pass-through of 1.054309 . The bounds test results indicate a strong long-term relationship between countercyclical monetary policy and market rates. These empirical findings suggest that the National Bank of Ukraine has been very effective in formulating and implementing its countercyclical monetary policy. In spite of the pervasive corruption, formidable political and economic challenges faced by the Ukrainian Republic over this sample period, these results are quite surprising.
\end{abstract}

Keywords: monetary policy, commercial banks, lending rate, interest rate pass-through, Central Bank key policy rate, Ukrainian Republic

DOI: http://dx.doi.org/10.15549/jeecar.v6i2.309

\section{INTRODUCTION}

Second to Russia, Ukraine had the second largest economy in the former U.S.S.R. The CIAWorld Factbook (2019) articulated that the Ukrainian economy was diversified, produced about four times the output of Kazakhstan -- the distanced third ranking republic in the former U.S.S.R. The Ukrainian economy contributed significantly to the former U.S.S.R in agriculture, large diameter pipes, vertical drilling apparatus and raw materials.
Yet, the Ukraine has suffered the most severe political and economic turmoil since the outset of its independence on August 24, 1991. Karatnycky (2001) argued that, despite of turmoil and unrests, "the rudiments of democracy and a market economy did manage to take root, however, and by 1999 Ukraine had begun to right itself."

In the face of difficult political conditions and economic turmoil, Ukraine transformed its banking system. This transformation process included the formation of the Central Bank; the 
introduction of coupon-karbovanets; the currency reform; the establishment of engraving facilities to mint coins and to print currency for circulation; streamlined regulatory provisions in the monetary sphere to establish the Ukrainian market based national currency and banking system.

Historically, Sochan (2011) argued that the current structure of the banking system in Ukraine was initiated under perestroika in the Soviet Union in the late 1980s. At the time of the declaration of independence in 1991, 73 banking institutions were registered in Ukraine. Among these institutions, Oschadny Bank and Ukreximbank were the two state-owned banks and 71 others were private joint-stock commercial banks. The role of the National Bank of Ukraine (NBU), the Central Bank of Ukraine, essentially exists as a theoretical concept.

As reported by Gegenheimer (2005), a legal advisor to the National Bank of Ukraine project for eight years, from 1997 until its completion in 2005, shortly after its independence, the Banking Supervision Project in Ukraine initiated by the U.S. Agency for International Development in 1995, had provided technical assistance to the NBU. This project was closed in September 2005. On the closing of the project, Gegenheimer (2005) argued, "The timing of the closure is unfortunate; because it comes at the very time when Ukraine just introduced the marketoriented reforms; when the international expertise would be particularly important to bring the Ukrainian financial sector in closer to the international standards and practices."

In the description of the Ukrainian monetary policy, the NBU stated that the primary objective of monetary policy of the National Bank of Ukraine, as defined by the Law of Ukraine "On the National Bank of Ukraine", is to achieve and maintain price stability in the country. The interest rate, the key policy rate, set by The Board of the National Bank of Ukraine, is one of the main monetary policy instruments.

Financial intermediation as a critical facilitator for investment and economic growth is welldocumented (Schumpeter, 1912; Patrick, 1966; McKinnon, 1973). Commercial banks play a crucial role in determining the spread between the lending rate and the cost of funds or the intermediation premium. As argued by Nguyen
(2015), "in addition to creating interest income to financial intermediaries, the intermediation premium affects the economy's savings, investment and consumption levels and hence the effectiveness of Central Bank's countercyclical monetary policies. Naturally, changes in consumption or investment, in turn, would change unemployment, inflation and gross domestic product, which would affect economic development and social progress."

Given the aforementioned persistent political and economic turmoil and the importance of the effectiveness of the intermediating function of commercial banks, the objective of this investigation is to evaluate the effectiveness of the Ukrainian countercyclical monetary policy as measured by the nature of the interest rate passthrough from January 2000 to November 2018 or the post-1999 era. January 2000 was shortly after the time at which Karatnycky (2001) posited that Ukraine had begun to right itself. The remainder of this paper is organized as follows. The following section briefly characterizes the Ukrainian economy and the banking sector. The next section provides a short review of literature. Following that is a description of the methodological issues and model's specification for investigation. The next section discusses the empirical results. The article ends with some concluding remarks.

\section{UKRAINIAN ECONOMY AND BANKING SECTOR}

\section{Ukrainian Economy and Corruption}

The Ukrainian pervasive corruption is a severe problem. In evaluating the progress of the Ukrainian economy, Heritage Foundation 2019 Index of Economic Freedom: Country Ranking articulated, "Progress has lagged on many muchneeded but contentious structural reforms such as cutting subsidies and raising energy tariffs, fiscal consolidation, and the fight against corruption. The greater inflows of remittances significantly contributed to the improvement of Ukraine's oligarch-dominated economy in 2018. Western institutions had less leverage to press for further reforms to make the country more democratic, and transparent; Ukraine needs to develop its capital markets, privatize state- 
owned enterprises, and improve both its legal framework and the rule of law to be prosperous."

The recent Ukrainian national budget shortfalls have been very severe so that the government has to borrow heavily from other countries, International Monetary Fund, and World Bank to meet its obligations to the populace and service its sovereign debts. The major cause of the budget deficits is the "shadow" economy, precipitated by corruption and high taxes. In 2019, the Ukrainian authority imposes 18.00 percent income tax, 1.50 percent military tax, and 22.00 corporate tax. Consequently, an increase in net personal income of 1.00 Ukrainian Hryvnia, the Ukrainian currency (UAH), leads to an increase in labor cost for Ukrainian businesses by $1.50 \mathrm{UAH}$. These taxes in a highly corrupt country naturally lead to expanding the underground segment of the economy, which results in larger losses of the government's tax revenue. To promote exports, the government refunds a portion of indirect taxes to exporters, through corrupted officials, many entities in the economy fabricate export documents to obtain refunds, which decrease the government's tax revenue. Prices of big-ticket items, such as vehicles and real estate, are understated to evade taxes. The tell tales of the Ukrainian shadow economy is that the national consumption is much larger than personal income.

Consequently, Ukraine must significantly eradicate the levels of corruption to provide an investment climate that would attract large and consistent flows of foreign capital, and to prepare the country for its stated ambition of drawing closer to the European Union.

As reported by Hitch and Kuchma (2011), to rectify the corruption problems, Ukraine enacted the new Law of Ukraine "On the Prevention of and Counteraction against Corrupt Practices". The "New Law", was adopted by the Verkhovna Rada, the Parliament, on April 7, 2011, signed by Ukrainian President Victor Yanukovych on June 7, 2011, and became effective on July 1, 2011. Hitch and Kuchma (2011) argued that "by introduction of this new law, Ukraine has demonstrated that it is making a serious effort to deal with the absolutely, incredibly difficult, onerous, and continuous problem. Unfortunately, despite of the New Law, Ukrainian corruption has become a threat to the country's democratic future and economic prosperity."

\section{Ukrainian Banking Sector}

Sochan (2011) also reported that the first commercial banks with private ownership under perestroika were registered in 1988. At the time of the declaration of independence in 1991, the state-owned banks accounted for almost all commercial banking operations. The less than one hundred newly formed commercial banks under private ownership were an insignificant portion of the financial structure of the country. In 1990, Agroprombank, Promstroibank, and the Social Investment Bank, three of the five sectoral banks in Ukraine, transformed themselves into joint-stock companies as Bank Ukraina, Prominvest, and Ukrsotsbank.

Sochan (1998) further argued, "The independent Ukrainian banking system began to form naturally during 1991 as the disintegration of the Soviet state gathered momentum. In March 1991, the republic adopted a law on 'Banks and Banking' that provided for the establishment of the National Bank of Ukraine from the Ukrainian Republican Division of the State Bank of the U.S.S.R." According to Sochan (1998, p. 71), "by the summer of 1991, the instructions from the Soviet State Bank were no longer binding on Ukraine. In December 1991, the U.S.S.R. State Bank was formally liquidated, and the National Bank of Ukraine became the effective central banking authority. A two-tiered banking system was envisaged under the law, wherein the National Bank would act as a central bank and all other banks would be responsible for commercial banking transactions."

As to the progress in the financial sector, the International Monetary Fund (IMF) (2019) reported, "The NBU is strongly committed to continue with prudent monetary and exchange rate policies, to anchor inflation expectations and build stronger reserve buffers. The monetary policy stance is appropriate to bring inflation down gradually to within the NBU's inflation target by early 2020. As inflationary pressures ease, the policy rate can be gradually reduced, but should remain sufficiently high to enable the NBU to steer inflation within the target band and to continue to buy foreign exchange, which is necessary to build stronger reserve buffers. This 
will also allow the NBU to continue with a gradual elimination of the remaining exchange restrictions, administrative controls, and capital flow measures in line with the agreed roadmap and the recently approved currency law that provides a new legal framework for currency operations."

IMF (2019) also reveals, "Several initiatives are underway to facilitate non-performing loans (NPLs) resolution. Little progress has been made in reducing NPLs in the last two years, despite the adoption of a law to facilitate out-of-court restructuring and the removal of tax impediments to the NPLs resolution. In this regard, the authorities are taking further actions to encourage NPL workouts. In October 2018, a new insolvency law was approved by parliament. A policy framework for NPLs restructuring in state-owned banks is under preparation. In addition, the NBU, with technical support from the World Bank, is working on a regulation, in line with the European Central Bank's (ECB) approach, to provide guidance to banks on how to reduce their NPL portfolios."

Finally, IMF (2019) stated, "The authorities would step up efforts to recover assets from failed banks and hold banks' former owners accountable as envisaged by the Banking Law and the law on the Deposit Guarantee Fund (DGF). Progress in disposing of failed banks' assets by the DGF has so far been limited. The authorities reiterated their determination to accelerate the recovery and sale processes to reduce the cost of bank failures to the state, including via ongoing litigation. In addition, they are committed to seeking compensation from former bank owners and related parties, in line with provisions in the Banking and DGF laws. They will publish the list of all former shareholders of resolved banks that are yet to honor their debts to the failed institutions, as ruled by court decisions. In addition, they will publish regular progress reports on asset recovery and litigation efforts (a structural benchmark)."

\section{REVIEW OF LITERATURE}

As summarized by Nguyen $(2015,2017)$, the literature on interest pass-through is relatively new. Espinosa-Vega and Rebucci (2003) applied a standard Error Correction Model to determine if interest rate pass-through in Chile's experience was atypical compared to ten other countries, including the United States. The authors found that the interest rate pass-through in the Chilean banking sector was incomplete and generally faster than the ones in the rest of the countries in the sample. The authors further argued that the adjustment process was affected by institutional changes in the exchange rate regime and Chile's monetary policy targeting. Nguyen (2017) investigated the nature of the Brazilian interest rate pass-through from January 1997 through June 2016 and concluded that the Brazilian lending rate was sticky in the short run, the passthrough is over-shooting in the long run, and a long countercyclical monetary policy impact lag.

Sørensen and Werner (2006) compared the interest rate pass-through across Euro-area and reported evidence of a high-degree of heterogeneity in the pass-through of base rates to bank interest rates. Alencar (2003) investigated the speed of pass-through effects from changes in the Brazilian benchmark interest rates and compared them to those observed in retail banking. The author argued that a significant degree of competition has driven Brazilian banks to operate efficiently.

Borio and Fritz (1995) and Cottarelli and Kourelis (1994) concentrated more specifically on the pass-through of policy rates to lending rates, which is also the focus of this investigation. Moreover, the monetary policy regime can affect adjustments and volatility of retail rates. For example, Mojon (2000) argued that nominal prices adjust faster or the pass-through is larger when inflation is higher. Sander and Kleimeier (2004) posited that bank competition, development of financial markets and banking system ownership are important factors of the country's financial structure. If financial markets are well developed, financially solid businesses tend to rely on alternative sources of finance when retail rates rise, increasing overall risks of banks' loan portfolios. In that case, banks increase lending rates to compensate for higher risks instead of rationing credit.

Dhal and Ansari (2013) studied the Indian commercial banks' loan pricing decisions and reported that loan prices depend upon alternative measures of loan interest rate and spreads. The authors also found that the pass- 
through from the policy rate to loan interest rates could be limited when commercial banks consider several factors including the policy rate for their loan pricing decisions.

Nguyen et al. (2017) investigated the Russian interest rate pass-through from February 2011 to November 11, 2016 and found a short-run interest pass-through of 0.662937 and a long-run interest rate pass-through of 0.826353 . The authors reported no long-term relationship between countercyclical monetary policy and market rates, as evidenced by bounds test results. Nguyen (2018) also studied the Mexican interest rate pass-through during the post-U.S. subprime mortgage crisis and found a very high short-run and an almost complete long-run interest rate pass-through. The bounds test revealed a long-term relationship between countercyclical monetary policy and market rates.

\section{METHODOLOGY AND MODEL SPECIFICATION}

\section{Structural Break and its implication}

In the age of globalization, every economy has experienced economic shocks. These shocks would in turn cause long time-series data to experience structural breaks. Model misspecification may result, if structural breaks are not accounted for in the model specification. In financial markets, the structure of interest rate breaks usually occurs because of economic shocks, and the Central Bank often reacts by implementing countercyclical monetary policy measures.

To account for possible structural breaks, this analysis follows Nguyen (2015) to define the spread, denoted by $S P_{t}$, as the difference between the two-time series. To search endogenously for the possibility of any structural break in the relationship between the two-time series, this study utilized Perron's (1997) endogenous unit root test function with the intercept, slope, and the trend dummy to test the hypothesis that the spread has a unit root.

$$
S P_{t}=\mu+\theta D U+\alpha t+\gamma D T+\delta D\left(T_{b}\right)+\beta S P_{t-1}+\sum_{i=1}^{k} \psi_{i} \Delta S P_{t-i}+v_{t}
$$

where $D U=1\left(t>T_{b}\right)$ is a post-break constant dummy variable; $t$ is a linear time trend; $D T=1\left(t>T_{b}\right)$ is a post-break slope dummy variable; $D\left(T_{b}\right)=1\left(t=T_{b}+1\right)$ is the break dummy variable; and $v_{t}$ are white-noise error terms. The null hypothesis of a unit root is stated as $\beta=1$. The break date, $T_{b}$, is selected based on the minimum t-statistic for testing $\beta=1$ (Perron, 1997).

The common methodology to account for a structural break is to introduce a dummy independent variable $d_{t}$ with the value of 1 from the structural break date onward and 0 elsewhere.

\section{Model Specification}

To investigate the nature of the Ukrainian interest pass-through, this study follows Wickens and Breusch (1988) and Pereira and
Maia-Filho (2013) to specify and estimate an Autoregressive Distributed Lag [ARDL $(n, m, s)$ ] model hypothesizing the relationship between the endogenous variable $i_{t}$, the independent variables $r_{t}$ and $d_{t}$.

$i_{t}=\mu+\sum_{j=1}^{n} \beta_{j} i_{t-j}+\sum_{k=0}^{m} \delta_{k} r_{t-k}+\sum_{l=0}^{s} \rho_{l} d_{t-l}+\varepsilon_{t}$

where $i_{t}$ is the lending interest rate and $r_{t}$ is the Central Bank's key policy rate at time $t$. As defined above, $d_{t}$ is a dummy variable to account for a structural break in the relationship between the lending rate and key policy rate. $\delta_{0}+\rho_{0}$ is the short-run passthrough - within the month after the Central Bank changes the key policy rate. It is a priori expectation that $0<\delta_{0}+\rho_{0} \leq 1 . \delta_{0}+\rho_{0}<1$ indicates sluggish adjustment, also known as lending rate stickiness. $\delta_{0}+\rho_{0}=1$ represents 
a complete pass-through in the short run. $\delta_{0}+\rho_{0}>1$ indicates overshooting

As Nguyen (2015) argued, "The ARDL method proposed by Pesaran et al. (1997) has been a valuable tool for testing the presence of long-run relationships between economic time-series. The advantage of the ARDL model is its ability to estimate both the long-term and short-term model parameters without requiring a pretesting to determine the order of the cointegration of the variables; thus, avoiding the problems posed by non-stationary time series. This pre-testing is particularly problematic in the unit-root cointegration literature where the power of the unit-root tests is typically very low, and there is a switch in the distribution function of the test statistics as one or more roots of the right-hand side variables process approach unity. Furthermore, the ARDL procedure is robust to small samples, allowing different optimal lags of variables."

As to the empirical estimation, Enders (2015) suggested that the process to estimate the coefficients for equation (1) is to utilize the Akaike information criterion to select the largest values of $n, m$ and s, deemed feasible; CUSUM and the CUSUM of Squares tests are used to test for model stability. Breusch-Godfrey Serial
Correlation Lagrange (LM) multiplier Test and Breusch-Pagan-Godfrey Heteroskedasticity Test are then used as diagnostics to test the hypotheses that the residuals $\left\{\varepsilon_{t}\right\}$ are white noises.

As proposed by Pereira and Maia-Filho (2013), given the estimation results for equation (2), the long- run effect is calculated as:

$$
\Phi=\frac{\sum_{k=0}^{m} \delta_{k}+\sum_{l=0}^{s} \rho_{l}}{1-\sum_{j=1}^{n} \beta_{j}}
$$

As articulated by Berstein and Fuentes (2003), $\Phi$ should be positive and close to 1 . $\Phi=1$ implies a complete pass-through in the long run, which can be considered evidence of significant competition in the banking system. If $\Phi<1$ or $\Phi>1$, it implies either stickiness (less than perfect pass-through) or overshooting, respectively, of retail rates with respect to changes in the policy rate.

It is also important to study the long-run relationship between countercyclical monetary policy and market rates. To this end, this investigation again follows Pereira and MaiaFilho (2013) to use the bounds testing approach (Pesaran, Shin, and Smith, 2001) for the following error correction representation of the Autoregressive Distributed Lag model:

$$
\Delta i_{t}=\varphi+\sum_{j=1}^{n} \eta_{j} \Delta i_{t-j}+\sum_{k=0}^{m} \pi_{k} \Delta r_{t-k}+\sum_{l=0}^{s} \omega_{l} \Delta z_{t-l}+\lambda_{1} i_{t-1}+\lambda_{2} r_{t-1}+\lambda_{3} d_{t-1}+\varepsilon_{t}
$$

where $\Delta$ is difference operator and the null hypothesis of "non-existing of the long-run relationship" is stated as $\lambda_{1}=\lambda_{2}=\lambda_{3}=0$. The relevant $F$-statistics for the joint significance of the $\lambda^{\prime} s$ are calculated and compared with the critical values tabulated by Pesaran, Shin, and Smith (2001). If the estimated F-statistic is greater than the upper bound critical value, the variables are cointegrated. If it is below the lower bound, the null hypothesis cannot be rejected, i.e., there is no support evidence for long-run relationship between countercyclical monetary policy and market rates.

\section{THE DATA}

To investigate the aforementioned issues, this study uses the monthly Ukrainian lending rates $i_{t}$ and Central Bank key policy rate $r_{t}$ from January 2000, when Karatnycky (2001) argued that Ukraine had begun to right itself, through November 2018 to estimate the Autoregressive Distributed lag model. The time series data for the commercial lending rate is collected from the International Financial Statistics, published by the International Monetary Fund.

The IMF does not report any policy related rates by the Ukrainian authority. The monthly 
Ukrainian Central Bank key policy rate series is a transformation of the information on rates and the dates that the Board of the National Bank of
Ukraine announced, which is not in any of particular periodic cycles such as monthly or quarterly.

Figure 1. Ukrainian lending rate in the credit markets, Central Bank's key policy rate and its Spread (January 2000 to November 2018)

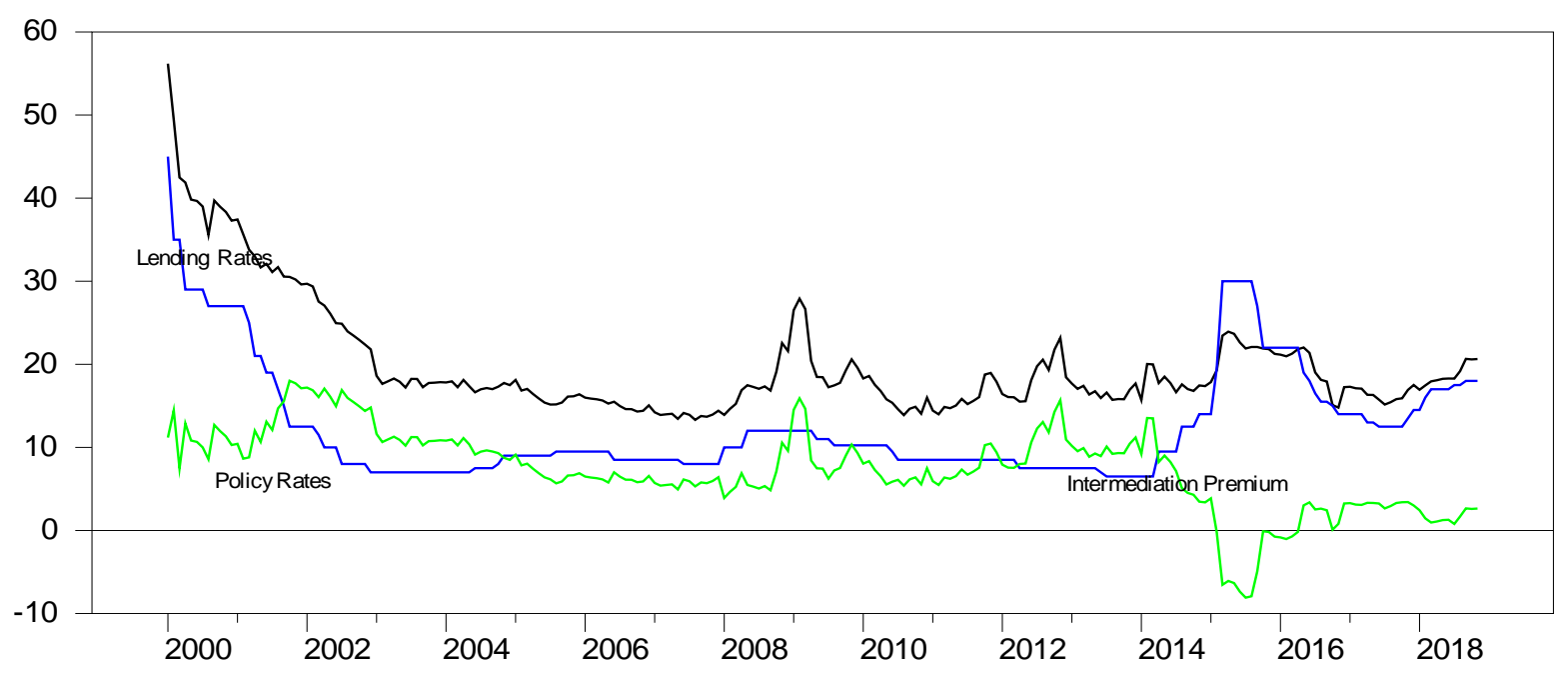

The rule of the transformation is to assign the value of the key policy rate, set by the Board of the National Bank of Ukraine that prevailed the longest in a given month as the key policy rate for that month. For example, if the Board of the National Bank of Ukraine set the key policy rate at 27.00 percent on August 28, 2015, 22.00 percent on September 25, 2015, and 20.00 percent on October 25 , then the monthly values of the transformed key policy rate will have the values of 27.00 percent for September and 22.00 percent on October 2015. Figure 1 illustrates the Ukrainian lending rate, Central Bank key policy rate and their spread.

The mean of the Ukrainian monthly lending rate during the sample period was 19.94 percent and ranged from 13.31 percent to 56.19 percent with a standard error of 6.89 percent. The mean Central Bank key policy rate over the same period was 12.55 percent and ranged from 6.50 percent to 45.00 percent with a standard error of 6.86 percent. Their correlation was 74.98 percent. The mean Central Bank key policy rate and monthly lending rate spread over the same period was 7.40 percent and ranged from -8.09 percent to 18.02 percent with a standard error of
4.86 percent.

\section{EMPIRICAL RESULTS}

The empirical results for this investigation are reported as follow.

\section{Structural Break}

The estimation results for Perron's (1997) endogenous unit root test function with the intercept, slope, and the trend dummy are summarized in Exhibit 2.

The estimation results reveal that both the post-break intercept dummy variable, $D U$, and the post-break slope dummy variable, DT, are positive and they are both insignificant at any conventional level. The break dummy, $D\left(T_{b}\right)$ is negative and is insignificant. The time trend, $t$, is negative and is significant at the 1.0 percent level. These results suggest that the Ukrainian intermediation premium follows a stationary trend process. Moreover, strength of the test statistic $t(\alpha=1)=-4.38599 \quad$ suggests the structural break in August 2008 
Exhibit 2. Perron's Endogenous Unit Root Test, Ukrainian Data - 2000:01- 2018:11

$S P_{t}=2.6537+0.4611 D U-0.0200 t+0.0066 D T-1.2287 D\left(T_{b}\right)+0.8424 S P_{t-1}+v_{t}$

$\begin{array}{llllll}\left(3.8997^{*}\right) & (0.6660) & \left(-2.9783^{*}\right) & (1.0078) & (-0.8678) & \left(23.4499^{*}\right)\end{array}$

\begin{tabular}{l|l|l} 
Number of augmented lags: $k=11$ & Break Date: August 2008 & $t(\alpha=1)=-4.38599 * * *$
\end{tabular}

Notes: Critical values for t-statistics in parentheses. Critical values based on $n=100$ sample for the break date (Perron, 1997). “"” and " ""*" indicate the significances at the 1.0 percent and the 10.00 percent levels, respectively.

As discussed in the methodology section and based on the Akaike information criterion, the estimation process indicates that the optimal values are $n=8, m=2$, and $s=9$ as the reported values for AIC in Exhibit 4 suggests, the ARDL (8, $2,9)$ model has the lowest AIC value, therefore, it will be used for this investigation. The estimation results and diagnostic statistics for the autoregressive model, ARDL $(8,2,9)$ are summarized in the following Exhibits 3, 4, and Figure 2 .

\section{ARDL Model}

Exhibit 3. Estimation Results for ARDL (8, 2, 9) Model and Bounds Test, 2000:01 - 2018:11

\begin{tabular}{|c|c|c|c|c|c|}
\hline \multicolumn{2}{|c|}{ ARDL (8, 2, 9): $i_{t}$ is a dependent variable } & \multicolumn{3}{l|}{ ARDL Bounds Test: $\Delta i_{t}$ is a dependent variable } \\
\hline Variables & Coefficient & t-statistic & \multicolumn{1}{l|}{ Variables } & \multicolumn{1}{l|}{ Coefficient } & t-statistic \\
\hline$i_{-1}$ & $0.892957^{*}$ & 11.69060 & $\Delta i_{-1}$ & -0.029800 & -0.484448 \\
\hline$i_{-2}$ & -0.079330 & -0.945942 & $\Delta i_{-2}$ & $-0.109130^{* * *}$ & -1.945254 \\
\hline$i_{-3}$ & 0.171902 & 1.538617 & $\Delta i_{-3}$ & 0.062772 & 1.122258 \\
\hline$i_{-4}$ & -0.139266 & -1.443978 & $\Delta i_{-4}$ & -0.076495 & -1.429662 \\
\hline$i_{-5}$ & -0.028245 & -0.357649 & $\Delta i_{-5}$ & $-0.104739^{* *}$ & -1.970320 \\
\hline$i_{-6}$ & -0.058235 & -0.727978 & $\Delta i_{-6}$ & $-0.162974^{*}$ & -3.090243 \\
\hline$i_{-7}$ & 0.102316 & 1.427362 & $\Delta i_{-7}$ & -0.060658 & -1.175716 \\
\hline$i_{-8}$ & 0.060658 & 1.336962 & $\Delta r_{0}$ & $0.195322^{*}$ & 3.185680 \\
\hline$r_{0}$ & $0.195322^{* *}$ & 2.123057 & $\Delta r_{-1}$ & $0.109289^{* * *}$ & 1.735823 \\
\hline$r_{-1}$ & -0.046565 & -0.395706 & $\Delta d_{0}$ & 0.528778 & 0.570296 \\
\hline$r_{-2}$ & $0.109289^{* *}$ & -2.456770 & $\Delta d_{-1}$ & -0.135554 & -0.146952 \\
\hline$d_{0}$ & $0.528778^{*}$ & 4.041952 & $\Delta d_{-2}$ & $2.612397^{*}$ & 2.837351 \\
\hline$d_{-1}$ & $-0.622362^{*}$ & -4.962115 & $\Delta d_{-3}$ & $3.747864^{*}$ & 3.998392 \\
\hline$d_{-2}$ & $2.747950^{*}$ & 24.42588 & $\Delta r_{d-4}$ & -0.156228 & -0.162812 \\
\hline$d_{-3}$ & $1.135468^{*}$ & 5.273541 & $\Delta d_{-5}$ & $5.406504^{*}$ & 5.693069 \\
\hline$d_{-4}$ & $-3.904092^{*}$ & -17.24629 & $\Delta d_{-6}$ & $2.077902^{* *}$ & 2.041524 \\
\hline$d_{-5}$ & $5.562732^{*}$ & 14.58965 & $\Delta d_{-7}$ & 0.648695 & 0.637258 \\
\hline
\end{tabular}


Exhibit 3. (Continued)

\begin{tabular}{|c|r|r|c|c|c|}
\hline$d_{-6}$ & $-3.328602^{*}$ & -7.105381 & $\Delta d_{-8}$ & $-5.071070^{*}$ & -5.011583 \\
\hline$d_{-7}$ & $1.429207^{* *}$ & -2.524948 & $i_{-1}$ & $-0.077243^{*}$ & -4.286429 \\
\hline$d_{-8}$ & -5.719765 & -8.455662 & $r_{-1}$ & $0.039468^{* *}$ & 2.513869 \\
\hline$d_{-9}$ & $5.071070^{*}$ & 10.72943 & $z_{-1}$ & 0.041969 & 0.291691 \\
\hline constant & $0.815184^{*}$ & 3.839288 & constant & $0.815184^{*}$ & 2.861512 \\
\hline $\begin{array}{l}R^{2}=0.970837 \\
\text { and }\end{array}$ & $\bar{R}^{2}=0.967712$ & $R^{2}=0.460087$ and & $\bar{R}^{2}=0.402239$ & \\
\hline $\begin{array}{l}F \text {-value }= \\
310.7033^{*}\end{array}$ & and AIC $=2.748022$ & $F$-value $=7.953403^{*}$ & and Bounds Test $F=6.530816, k=2$ \\
\hline
\end{tabular}

Note: “*”, “*” and “***” indicate 1 percent, 5 percent and 10 percent significance levels, respectively.

Critical values for bounds tests at 10 percent: $\mathrm{I}(0)=2.713$, I $(1)=3.453 ; 5$ percent: $\mathrm{I}(0)=3.235$, $\mathrm{I}(1)=4.053$;

1 percent: $\mathrm{I}(0)=4.358, \mathrm{I}(1)=5.393$.

The left panel of Exhibit 4 reports the diagnostic tests testing for the correlation among the independent variables and the possibility for the variance of the error term to depend on regressors included in the estimated the model.
The right panel of Exhibit 4 reveals the AICvalues of the five best estimated models.

Exhibit 4. Diagnostic Tests and Five Best Models According to AIC Criteria; 2000:01-2018:11

\begin{tabular}{|l|ll|}
\hline \multicolumn{1}{|c|}{ Diagnostic Tests } & \multicolumn{2}{c|}{ Model Selection Criteria } \\
\hline Breusch-Godfrey Serial Correlation LM Test: & Five Best Models & \multicolumn{1}{c|}{ AIC } \\
\cline { 2 - 3 }$H_{0}:$ No serial correlation at up to 2 lags. & ARDL $(8,2,9)$ & 2.753188 \\
$\mathrm{~F}_{(2,194)}=0.175193, \quad$ p-value $=0.8394$ & $\operatorname{ARDL}(7,2,9)$ & 2.754129 \\
\hline Breusch-Pagan-Godfrey Heteroskedasticity Test: & ARDL $(8,2,10)$ & 2.756115 \\
$H_{0}:$ Homoskedasticity. & ARDL $(7,2,10)$ & 2.756517 \\
$\mathrm{~F}_{(21,196)}=1.293614, \quad$ p-value $=0.1828$ & & \\
\hline
\end{tabular}

Note: data is from calculations by authors.

Figure 2 illustrates the graphs of the CUSUM period. and the CUSUM of Squares Tests over the sample 

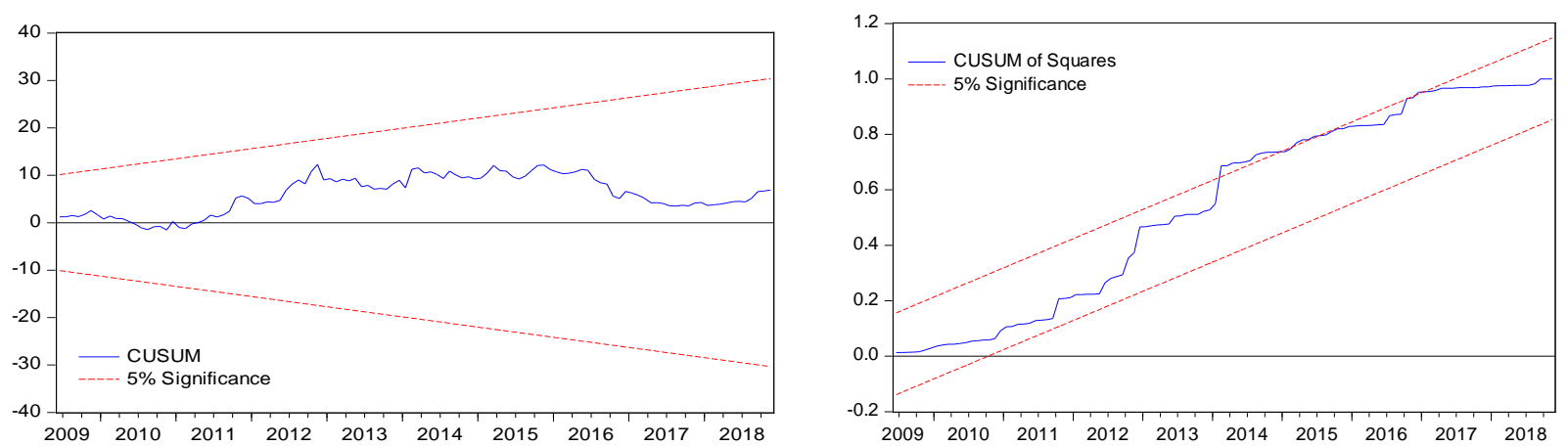

Figure 2. Graphs of CUSUM and CUSUM of Squares tests to test for stability of model's estimated parameters.

An analysis of the overall estimation results indicates that there is no serial correlation and that the model exhibits strong predictive power, as evidenced by the strengths of the BreuschGodfrey Serial Correlation Lagrange Multiplier Test $\mathrm{F}_{(2,194)}=0.175193$ with the $\mathrm{p}$-value $=0.8394$, which fails to reject No serial correlation at up to 2 lags. The Breusch-Pagan-Godfrey Heteroskedasticity $F_{(21,196)}=1.293614$ with the pvalue equal 0.1828 , which also fails to reject the null hypothesis of Homoskedasticity. As Figure 2 illustrates, the CUSUM Test fell well in the band of 5.0 percent level of significance, and, except for the year 2014, the CUSUM of Squares Test fell well in the band of 5.0 percent level of significance, over the sample period. These empirical findings indicate the stabilities of the estimated parameters of the model over the sample period. Overall, the diagnostic analysis indicates that the estimated $\operatorname{ARDL}(8,2,9)$ model is very reliable.

As reported in Exhibit 3, the estimated sum of $\delta_{0}+\rho_{0}$ is $0.72410 \quad(0.195322+0.528778=$ $0.72410)$. In addition, using the equation (3), the following calculation indicates that the estimated long-run interest rate pass-through rate in the Ukrainian banking system is $\Phi=$ 1.054309 .

$\Phi=\frac{\sum_{k=0}^{m} \delta_{k}+\sum_{l=0}^{s} \rho_{l}}{1-\sum_{j=1}^{n} \beta_{j}}=\frac{0.039468+0.041970}{1-0.922757}=\frac{0.081438}{0.077243}=1.054309$

Finally, to test the null hypothesis of "nonexistence of the long-run relationship$H_{0}: \lambda_{1}=\lambda_{2}=\lambda_{3}=0$ ", the calculated value of the relevant $F$-statistic being 6.530816 for the joint significance of the hypothesis is compared to the critical values of the lower and upper bounds at the 5.0 percent levels of significance. Comparing the value of the F-statistic of 6.530816 to the critical value of the lower bound $\mathrm{I}(0)=3.235$ and the upper bound $\mathrm{I}(1)=4.053$ indicates that the null hypothesis of "nonexistence of the long-run relationship" in the Ukraine banking sector should be rejected. This testing result suggests that there is a long-term relationship between the Central Bank's key policy rate and the lending rate in the Ukrainian commercial banks' credit markets.

\section{DISCUSSION OF THE EMPIRICAL RESULTS}

The endogenous search process for breaks in the Ukrainian interest rate structure using Perron's (1997) endogenous unit-root test function with the intercept, slope, and the trend dummy revealed that the relationship between the Central Bank's key policy rate and the 
commercial bank's lending rate experienced a structural break in August 2008. This endogenously determined structural break may be attributable to the lingering impact of the disputed presidential election that precipitated the Orange Revolution, which had a negative impact on the Ukrainian economy and banking sector.

To account for the structural break, this investigation introduced a dummy variable $d_{t}$ to the model and assigned the value of 1.0 from August 2008 onward and 0.0 elsewhere over the sample period. An analysis of the overall estimation results indicates that there is no serial correlation and that the model exhibits strong predictive power and confirms that the estimated residuals are white noise.

The estimation results of the Autoregressive Distributed Lag, ARDL (8, 2, 9) model, represented by equation (2), reveal that the Ukrainian short-run rates of pass-through, $\delta_{0}+\rho_{0}=0.72410$, is relatively high as compared to empirical values reported in the literature for the emerging and advanced economies (Alencar, 20003; Pereira and Maia-Filho, 2013; Nguyen, 2017 and 2018; Wickens and Breusch, 1988).

Based on the Akaike information criterion, the longest lag retained by the estimation process for the commercial lending rate is $8\left(i_{-8}\right)$ and for the Central Bank key policy rate is $2\left(r_{-2}\right)$. These findings suggest that the Ukrainian commercial banks considered their lending rates 8 months back in determining their current lending rate; while these same lending institutions took only two months to respond to the monetary policies completely. The calculated long-run passthrough rate in the Ukrainian banking industry is $\Phi=1.054309$ which is marginally high, indicating that the Ukrainian Long-term interest rate pass-through is marginally overshooting, suggesting the marginally explosive response to the Central Bank's countercyclical monetary policy by commercial banks.

Finally, one way to measure the credibility of the Central Bank is the existence of the long-run relationship between its countercyclical monetary policy, as reflected in changes in the Central Bank's key policy rate and the commercial banks' lending rate in the credit markets. In this investigation, this issue is addressed by testing the above stated null hypothesis $H_{0}: \lambda_{1}=\lambda_{2}=\lambda_{3}=0$. The testing result indicated that this null hypothesis should be rejected, suggesting long-run relationship between the countercyclical monetary policy and the commercial banks' lending rate in the credit markets.

\section{CONCLUDING REMARKS}

Financial intermediation is a critical facilitator of investment and economic growth. Due to the use of the interest rate pass-through to change lending rates in the economy, which in turn transmits countercyclical monetary policy measures to consumption and investment activities, commercial banks are an integral part of the monetary policy transmission mechanism. The macroeconomic policy target variables of unemployment, inflation and real gross domestic product (GDP) are changed by changes in the levels of consumption and investment.

As stated above, the objective of this study is to investigate how Ukrainian commercial banks passed changes in their cost of funds due to countercyclical monetary policy, as reflected in changes in the Central Bank's key policy rate, to their customers through the short-run and long-run interest rate pass-through processes. The sample period is from January 2000, shortly after Karatnycky (2001) argued that Ukraine had begun to right itself, to November 2018.

To achieve the above objective, this study utilizes an Autoregressive Distributed Lag model to investigate the nature of interest rate pass-through in the Ukrainian banking sector. Estimation results suggest that, based on the Akaike information criterion, the $\operatorname{ARDL}(8,2,9)$ model best fits the data. Estimation results of the ARDL $(8,2,9)$ model reveal that the Ukrainian short-run rates of pass-through ( $\left.\delta_{0}+\rho_{0}=0.72410\right)$ is relatively high, as compared to empirical values reported in the literature for the emerging and advanced economies.

The empirical results also indicate that the Ukrainian commercial banks considered their lending rate up to eight months back in 
determining their current lending rate; while these same lending institutions took only two months to respond to the monetary policies completely. The calculated long-run passthrough rate in the Ukrainian banking industry is $\Phi=1.054309$ which is marginally high, indicating that the Ukrainian long-term interest rate pass-through is marginally overshooting, suggesting the marginal explosiveness of the Central Bank's countercyclical monetary policy.

The result of the testing procedure testing the null hypothesis $H_{0}: \lambda_{1}=\lambda_{2}=\lambda_{3}=0$ suggested that the null hypothesis should be rejected at any conventional level of significance, suggesting a strong long-run relationship between the countercyclical monetary policy and the commercial banks' lending rate in the credit markets. The rejection of above null hypothesis of no long-run relationship is an indication that the National Bank of Ukraine enjoyed a great deal of credibility in conducting its countercyclical monetary policy.

Understanding the behavior of bank interest rates is relevant to conducting monetary policy and to designing public policies. This investigation studies the nature of interest rate pass-through in the Ukrainian economy. The empirical findings of this study suggest that the Ukrainian Central Bank has been very effective in formulating and implementing its countercyclical monetary policy. In spite of the pervasive corruption problems, large shadow economy, formidable political and economic challenges faced by the Ukrainian Republic over this sample period, these results are very surprising.

\section{REFERENCES}

Alencar, L. S. (2003) O pass-through da taxa básica: Evidência para as taxas de juros bancárias. In: Banco Central do Brasil. Relatório de Economia Bancária e Crédito, pp. 90-100.

Borio, C., and Fritz, W. (1995) The response of short-term bank lending rates to policy rates: a cross-country perspective. BIS Working Papers, No 27.
CIA-World Factbook. 2019. Europe: Ukraine. U.S. Central Intelligence Agency. https://www.cia.gov/library/publications/th e-world-factbook/geos/up.html

Cottarelli, C., and Kourelis, A. (1994) Financial Structure, bank lending rates, and the transmission mechanism of monetary policy. IMF Staff Papers 41(4), pp. 587-623.

Dhal, S. C., and Ansari, J. (2013) Interest Rate Pass-through and Determinants of Commercial Banks' Loan Pricing Decisions in India: Empirical Evidence from Dynamic Panel Data Model. Banking \& Finance Review. Vol. 5 Issue 1, pp. 91-113.

Espinosa-Vega, M., and Rebucci, A. (2003) Retail bank interest rate pass-through: Is Chile atypical?, IMF Working Paper 03/112, 35p.

Gegenheimer, A.G. (2005) Bank Regulatory Reform in Ukraine. The International Lawyer, Vol. 39, No. 4 (WINTER 2005), pp. 843-876. American Bar Association. https://www.jstor.org/stable/40708000

Heritage Foundation. (2019) Freedom from Corruption Index-Country Rankings. The Global Economy.com. https://www.theglobaleconomy.com/ranki ngs/herit_corruption/

IMF. (2019) Ukraine Request for Stand-by Arrangement and Cancellation of Arrangement under the Extended Fund Facility-Press Release: Staff Report; and Statement by the Executive Director for Ukraine. IMF Country Report No. 19/3, (January 2019), Washington, D.C., US.

Hitch, J.T., and Kuchma, Y. (2011) Ukraine's New Anti-Corruption Law: Will It Really Stop Corruption in Ukraine? The International Lawyer, Vol. 45(3) (fall 2011), pp. 839-855.

Karatnycky, A. (2001) Meltdown in Ukraine. Foreign Affairs, Vol. 80, No. 3 (May - June 2001), pp. 73-86. Council on Foreign Relations. https://www.jstor.org/stable/20050152

McKinnon, R. I. (1973) Money and Capital in Economic Development. Washington, DC: Brookings Institute.

Mojon, B. (2000) financial structure and the 
interest rate channel of ECB monetary policy.

European Central Bank Working Paper Series $40,45 \mathrm{p}$.

National Bank of Ukraine. Description of Monetary Policy. https://bank.gov.ua/control/en/publish/arti cle?art_id=31973143\&cat_id=31973142)

Nguyen, Chu V. (2018) The Mexican Interest Rate Pass -Through in the Post U.S. Subprime Mortgage Crisis Era, the International Trade Journal, 2018. Routledge-Taylor \& Francis Group. Vol. 32, Issue 1, pp. 100-115. https://doi.org/10.1080/08853908.2017.136 0226.

Nguyen, Chu V., Phan, D. K., and Williams, M. (2017) The Transmission Mechanism of Russian Central Banks Countercyclical Monetary Policy since 2011: Evidence from the Interest Rate Pass-Through, Journal of Eastern European and Central Asian Research, 2017. DOI:

http://dx.doi.org/10.15549/jeecar.v4i2.165

Nguyen, Chu V. (2017) The Brazilian Interest Rate Pass- Through. Journal of Business and Economic Perspectives, Vol. 44 (1), pp. 29-39.

Nguyen, Chu V. (2015) The Vietnamese Lending Rate, Policy Related Rates, and Monetary Policy Post-1997 Financial Crisis, Cogent Economics and Finance, pp. 1-13. http://dx.doi.org/10.1080/23322039.2015.1 007808

Patrick, H. T. (1966) Financial Development and Economic Growth in Underdeveloped Countries. Economic Development and Cultural Change, Vol. 14, No 2, pp. 174-89.

Pereira, C. M., and Maia-Filho, L.F. (2013) Brazilian Retail Banking and the 2008 Financial Crisis: Were the GovernmentControlled Banks that Important? Journal of Banking \& Finance, Vol. 377), pp. 22102215.

Perron, P. (1997) Further Evidence on Breaking Trend Functions in Macroeconomic Variables. Journal of Econometrics, 80. pp. 355-385.
Pesaran, M. H., Shin, Y., and Smith, R. (2001) Bounds Testing Approaches to the Analysis of Level Relationship. Journal of Applied Econometrics, Vol. 16, pp. 289-326.

Sander, H., and Kleimeier, S. (2004) Convergence in euro-zone retail banking. What interest rate pass-through tells us about monetary policy transmission, competition and integration? Journal of International Money and Finance, Vol. 23(3), pp. 461-492.

Schumpeter, J. A. (1912). Theorieder WirtschaftlichenEntwicklung, Liepzig: Duncker and Humblot. Revised English translation by Redvers Opie. The Theory of Economic Development. Cambridge, MA: Harvard University Press, 1934.

Sochan, P. (1998) The Banking System in Ukraine. Russian \& East European Finance and Trade, Vol. 34(3), Monetary Questions in Ukraine (May - Jun. 1998), pp. 70-93. https://www.jstor.org/stable/27749441

Sørensen, C. K., and Werner, T. (2006) Bank interest rate pass-through in the Euro area: A cross-country comparison. European Central Bank Working Paper Series 580, 63p.

Wickens, M., and Breusch, T. (1988) Dynamic specification, the long run and the estimation of transformed regression models. Economic Journal, 98, pp. 189-205. 


\section{ABOUT THE AUTHORS}

Chu V. Nguyen, email: NguyenChu@uhd.edu

Dr. Chu V. Nguyen is an Associate Professor of Economics and Finance and former Chair of the FAEIS Department at the Marilyn Davies College of Business, University of HoustonDowntown. He earned an MA in Economics, an MS in Mathematics and a $\mathrm{PhD}$ in Economics from the University of Cincinnati. $\mathrm{He}$ is the editor-in-Chief of the Southeast Asian Review of Economics and Business. He is also the Chairman of the Board of Directors of Tropical Star Enterprise, Inc. He once served as an economist and then the Head of the Economic Analysis and Forecasting Department at the 5th District of Federal Home Loan Bank System. He published over 85 publications in reputable US and international peer-reviewed journals.

Dr. Anna Kravchuk is a professor of Finance at the Academy of the State Penitentiary Service, Chernihiv, Ukraine. She earned an MS in Financial Management from the Kyiv National Economic University and a Doctor in Economics from the Ukrainian Academy of Banking. She is a member Editorial Board of the Scientific Journal "Scientific Reviewer of Siverschyny". She was a member of the Council for the protection of doctoral dissertations at the Ukrainian Academy of Banking. She published over 150 publications in reputable Ukraine and international peer-reviewed journals. Conducts research in the field of monetary processes and insurance business. 